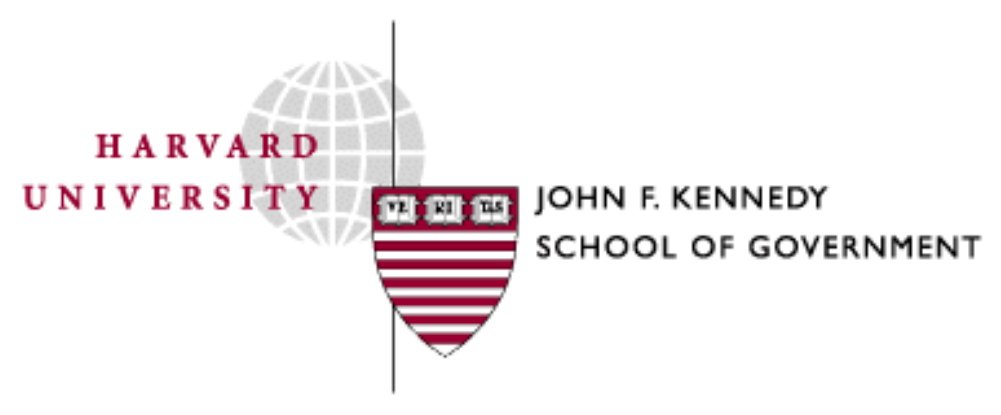

Faculty Research Working Papers Series

Poverty and Place in North America

Mary Jo Bane and Rene Zenteno

April 2005

RWP05-035

The views expressed in the KSG Faculty Research Working Paper Series are those of the author(s) and do not necessarily reflect those of the John F. Kennedy School of Government or Harvard University. Copyright belongs to the author(s). Papers may be downloaded for personal use only. 


\title{
Poverty and Place in North America Overview
}

\author{
By Mary Jo Bane \\ Kennedy School of Government, Harvard University \\ and Rene Zenteno \\ Escuela de Graduados en Administración Pública y Política Pública \\ Tecnológico de Monterrey
}

\author{
Conference on Poverty and Poverty Reduction \\ Monterrey Mexico January 20-21, 2005
}

This paper provides an overview of poverty in North America. In it we look at the three countries of North America-Mexico, the US, and to a lesser extent Canadaand attempt to both describe poverty as it exists in the three countries and explore some of the correlates of poverty.

In doing so, we attempt to bring together the concepts and approaches used mostly in studying poverty in developing countries and those used in developed countries. We propose some definitions of poverty that we believe can be usefully applied across very different countries. We explore some correlates of poverty in the three countries, and both the similarities and the differences in the correlates of poverty across the three. We take note of the policy issues that are raised by these relationships. As might be expected, we raise more questions that we answer, about both our approach and our findings.

We begin with an overview of growth and inequality in the three countries. The second section of the paper presents concepts and measures of poverty and reports the overall incidence of poverty in the three countries using various measures. The third section explores the relationship between the level of economic development and poverty, both between and within countries. The fourth section looks at the relationships between household composition and poverty and between race/ethnicity and poverty in the US and Mexico. The final section briefly raises policy issues that emerge from the analysis.

\section{Growth and Inequality}

Since the early 1990's enormous progress has been made in conceptually linking the notions of economic growth, distribution and poverty. Evidence has emerged on the relationships between growth, income distribution and monetary poverty (Datt and Ravaillon, 1992). As examined by Son and Kakwani (2004), initial levels of economic development and income inequality can have significant impacts on poverty reductions. Also, there is no question that long-term poverty reduction needs to be built on sustained economic growth. However, even in a context of economic growth, what happens to 
poverty depends on what happens to the distribution of income and consumption (Deaton, 2003).

In understanding the dynamics of poverty in North America, we must first look at recent trends in economic growth and inequality in the region. The story is different depending on where you live in North America. Table 1 shows the economic and social conditions prevailing in the region. With a population of 431.7 million people, North America is one of the most populous regions in the world. Almost seven out of every ten persons in the region live in the United States. Second in population size is Mexico, with 106.2 million people (24 percent). Canada accounts for less than one-tenth of the population. Most of the population in the NAFTA region lives in urban settings, and the countries do not differ greatly in their levels of urbanization, ranging from 75 percent of the population in Mexico to 79 percent in Canada and U.S.

Table 1. Canada, Mexico and U.S. at a Glance, 2004.

\begin{tabular}{|c|c|c|c|}
\hline & Canada & Mexico & US \\
\hline Population (millions) ${ }^{1}$ & 31.9 & 106.2 & 293.6 \\
\hline Percent Urban Population ${ }^{1}$ & 79 & 75 & 79 \\
\hline \multicolumn{4}{|l|}{ Gross Domestic Income in Purchasing } \\
\hline Power Parity Per Capita, 2003 (US\$) ${ }^{2}$ & $\$ 31,400$ & $\$ 9,300$ & $\$ 37,600$ \\
\hline Life Expectancy at Birth ${ }^{1}$ & 79 & 75 & 77 \\
\hline Infant Deaths per 1,000 Live Births ${ }^{1}$ & 5.2 & 24.9 & 6.7 \\
\hline \multicolumn{4}{|l|}{ Average Years of Schooling Population } \\
\hline $25-64$ year-old ${ }^{2}$ & 12.9 & 7.4 & 12.7 \\
\hline
\end{tabular}

Sources: Statistics of the ${ }^{1}$ Population Reference Bureau and the ${ }^{2}$ Organisation for Economic Co-operation and Development.

North America is one of the richest regions of the world, comprising about onequarter of world output. By the World Bank's classification, Canada and the U.S. economies fall into the high-income grouping. Even though Mexico ranks as an upper middle-income economy in the world, its income per capita falls far behind those of Canada and the U.S. Average per-capita income is estimated to be 1.2 times greater in the United States than in Canada and 4.0 greater than in Mexico. With a per capita income of $\$ 9,300$, Mexicans have, on average, less than 30 percent of the income of their NAFTA partners. 
Although Canadians do not earn as much as Americans, they lead a better life in terms of other indicators of human development. A person born in Canada is expected to live, on average, 79 years and to have a chance of 5.7 in one-thousand of dying before the first year of life, compared to a new born in the U.S. whose life expectancy and infant mortality rate would be of 77 and 6.7, respectively.

Since the 1930s, as a result of a rapid expansion of the public health system, death rates have been declining so rapidly in Mexico that by now expectations of life at birth are virtually identical in Mexico and the U.S. However, the infant mortality rate -a key measure of quality of life- is still considerably higher in Mexico than north of the border. The risk of death during the first year of life is approximately four times higher in Mexico than in Canada and the U.S. A relatively high infant mortality rate in Mexico is closely related to the persistence of poverty and to high levels of economic and social inequality across regions and social groups.

Levels of educational attainment are similar in the US and Canada with Canada slightly higher; thus Canada’s lower GDI does not seem to result from a lower overall level of human capital. Educational opportunities are still much more restricted in Mexico. With an average number of years of education completed (among adults 25-64 years old) of 7.4, Mexico exhibits significantly lower levels of education than Canada or the United States.

The magnitude of income poverty is determined by the rate of economic growth and the distribution of income (Bourguignon, 2003). Figure 1 displays the trends in per capita income (PPP) for each NAFTA country from 1950 to 2000, expressed in 1996 dollars. Table 2 provides the average per annum growth rate of per capita income and population in these countries over the last four decades.

Two major results emerge from this information. First, while Canada and the United States were able to sustain a positive income growth over this period, Mexico experienced income stagnation during the last twenty years. Second, there is strong divergence over time in per capita income between México and its NAFTA partners. Long-run divergence in productivity levels and living standards between developed and developing countries has been documented by Lant Pritchett (1997). The absolute income gap between Canada and the U.S. has also widened since the mid-1980s, but still it looks small when compared to income differences between México and the U.S. 
Figure 1. Real Gross Domestic Product Per Capita in 1996 Constant Prices and U.S.-Canada U.S.-Mexico Income Ratios, 1950-2000.

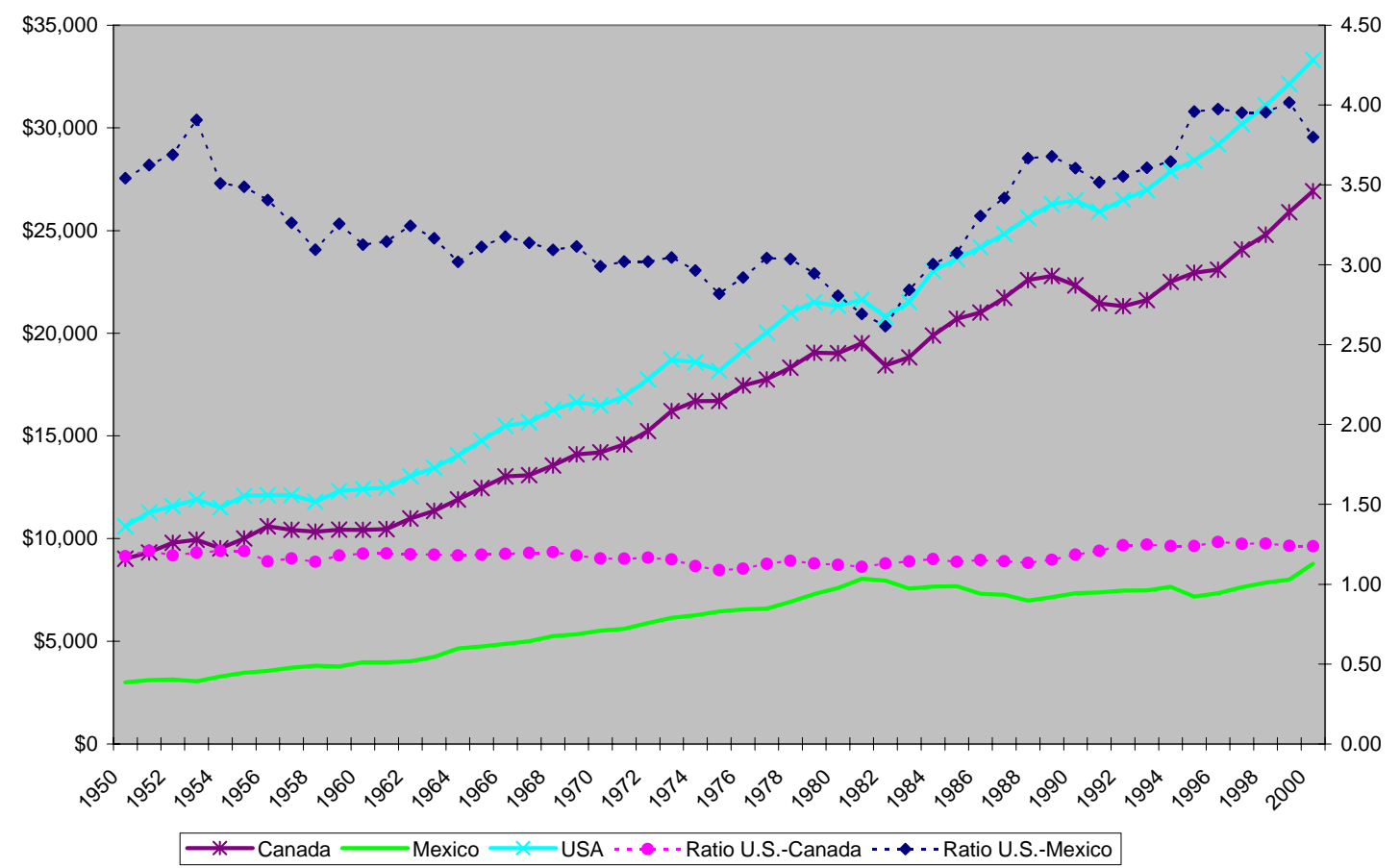

It is important to note that between 1961 and 1980, as Table 2 indicates, the Mexican economy expanded at a rate higher than Canada and the U.S. Per capita income in Mexico grew strongly on average in the 1970's, as it had in the previous decade (3.3 percent). Canada also experienced relatively high rates of economic expansion over this period. Meanwhile, per capita income growth averaged less than 3.0 percent in the U.S. The economic expansion allowed Mexico to reduce the U.S./Mexico income ratio to around 3.0 during the 1960s and 1970s, having its lowest point in 1982 (2.6). The rapid economic growth of Mexico did not have a significant impact on closing the income gap with its NAFTA partners, largely because of its fast demographic growth. As shown in Table 2, the Mexican population grew as fast as the economy from 1961 to 1980.

Table 2. GDP Per Capita and Population Annual Growth Rates, 1961-2000.

\begin{tabular}{|c|c|c|c|c|c|c|}
\hline & \multicolumn{2}{|c|}{ Canada } & \multicolumn{2}{|c|}{ Mexico } & \multicolumn{2}{|c|}{ US } \\
\hline & GDP & Population & GDP & Population & GDP & Population \\
\hline 1961-1970 & 3.2 & 1.7 & 3.4 & 3.3 & 2.9 & 1.3 \\
\hline 1971-1980 & 3.0 & 1.4 & 3.3 & 3.2 & 2.6 & 1.1 \\
\hline $1981-1990$ & 1.7 & 1.2 & -0.3 & 2.0 & 2.2 & 0.9 \\
\hline $1991-2000$ & 1.9 & 1.0 & 1.9 & 1.8 & 2.3 & 1.2 \\
\hline
\end{tabular}

Sources: Authors's calculations using data from World Penn Tables and Population Census Statistics. 
By the 1980s, however, much had changed. Canada experienced a significant decline of per capita income growth (from 3.0 to 1.7 percent) and Mexico suffered a substantial slowdown in its rate of economic expansion (from 3.3 to -0.3 percent) as a result of several economic crises. The 1990s were not particularly prosperous either for Mexico. Although Mexico’s per capita income growth averaged 1.9 percent during this decade, it experienced a major decline in living standards as a result of the Mexican “Tequila Crisis” of 1994-1995. ${ }^{1}$ Per capita income in the U.S. grew at an annual rate of 2.2 and 2.3 percent during the 1980s and 1990s, respectively. As a result of diverse economic performances, the ratio of per capita income between the U.S. and Mexico increased substantially during the last twenty years. The absolute income gap between Mexico and the U.S. rose from \$19,128 in 1990 to $\$ 24,542$ in 2000. Not surprisingly, Mexico-US migration and remittances have experienced a significant boost during the last 10 years.

Mexico not only fared worse than Canada and the United States over the 1980s and 1990s, but also continues to suffer a worse income distribution. Lower average income coupled with higher inequality, help to explain the difference in poverty outcomes between Mexico and its NAFTA partners. Although Mexico was able to reduce income inequality between 1963 and 1984, the situation has been more uneven during the years of economic restructuring and financial crisis (Hernandez Laos, 2003).

Recent trends in the distribution of income in North America are shown in Table 2, as measured by the Gini coefficient. The information shows two important features. On the one hand, Mexico is a more unequal country than Canada and the United States. Also, economic growth spreads its benefits more equitably in Canada than in the U.S. On the other hand, the overall trend in income distribution has been worsening in the three countries, rising particularly in Canada. As a result, differences in income inequality between Canada and U.S. seem to be closing over time.

Table 3. Gini Coefficientes. Canada, Mexico and U.S., 1984-2000.

\begin{tabular}{|c|c|c|c|c|c|}
\hline \multicolumn{2}{|c|}{ Canada } & \multicolumn{2}{|c|}{ Mexico } & \multicolumn{2}{|c|}{ US } \\
\hline 1987 & 0.283 & 1984 & 0.448 & 1986 & 0.335 \\
\hline 1991 & 0.281 & 1992 & 0.485 & 1991 & 0.336 \\
\hline 1994 & 0.284 & 1994 & 0.496 & 1994 & 0.355 \\
\hline 1998 & 0.305 & 1998 & 0.494 & 1997 & 0.372 \\
\hline 2000 & 0.302 & 2000 & 0.491 & 2000 & 0.368 \\
\hline
\end{tabular}

Source: Statistics of the Luxembourg Income Study.

\footnotetext{
${ }^{1}$ The scale of the graph and the PPP comparison do not allow to clearly observing the decline in per capita income in 1995.
} 
The importance of reducing inequality for poverty reduction in Mexico is illustrated in a hypothetical example by Bourguignon (2003). With no change in the distributions of income, if real per capita income in Mexico would grow at an annual rate of 3\% over a period of 10 years, poverty would be reduced by less than 7 percent. However, an absolute reduction of 0.1 on its Gini coefficient would represent a drop of more than $15 \%$ over the same period. Thus, it would take about 30 years to reach the same result without any change in the income distribution (Bourguignon, 2003).

In summary, data on the level of economic development, economic growth and income inequality show substantial differences among the US, Canada, and especially Mexico. All three of these dimensions are related to levels and trends in poverty in the three countries. After the discussion of poverty measures in the next section, we will return to these relationships and the issues they raise.

\section{Poverty Measures for North America}

In this paper, we make use of three conceptually different approaches to measuring income poverty:

- For some analyses, we use the official poverty or low income guidelines developed by and for the individual countries.

- We use the market basket poverty lines for food poverty and basic needs poverty in Mexico, adjusted for exchange rates and purchasing power parity, to estimate the incidence of poverty across countries.

- We also use a relative poverty line, defined as 50 percent of median household income for each country.

We believe that each of these approaches makes an important contribution to understanding poverty in North America.

National poverty lines. Each of the three countries' statistical agencies takes a somewhat different approach to measuring poverty or low income.

In 2002, Mexico developed for the first time an official poverty measure. An official technical committee has developed a market-basket approach to poverty measurement, which is explained in more detail in the paper by Cortes et. al (2002). Mexico uses three different poverty lines, one of which measures extreme or food poverty, and is set at the cost of purchasing a minimum diet. The second poverty line is meant to represent the cost of food plus education, and health; the third line is meant to represent the cost of purchasing basic needs. Mexico has defined different poverty lines for rural and urban areas. It expresses its poverty lines as consumption per person per day, with no adjustments for household size. Mexico's official poverty lines are shown below. 
Table 4. Poverty Lines for Mexico in US\$ Adjusted for

Purchasing Power Parity, Per Person Per Day, 2000.

\begin{tabular}{llll}
\hline & Rural & & Urban \\
Food & $\$ 2.49$ & & $\$ 3.38$ \\
Health and Education & $\$ 3.06$ & $\$ 4.00$ \\
All Basic Needs & $\$ 4.55$ & $\$ 6.76$ \\
\hline
\end{tabular}

Source: Authors's calculations using data from Cortés, et. a.l. (2002).

The United States developed a market-basket approach to poverty measurement in the 1960s. The cost of a basic nutritious diet, which became known as the Thrifty Food Plan, was estimated by the Department of Agriculture based on the eating habits of low income families and the prices of the foods eaten. The proportion of income that low income families spent on food was determined empirically through consumer expenditure surveys. The reciprocal of the proportion spent on food became the multiplier of food costs. The poverty line was estimated to be about three times the cost of the thrifty food plan. Poverty lines were estimated separately for households of different sizes and age compositions. The poverty line is not adjusted for rural-urban residence or for region of the country. It has been updated annually using the Consumer Price Index for the country as a whole. US poverty lines are normally reported as annual income measures that vary by household size. ${ }^{2}$ The annual income poverty cut-offs and the weekly cost of the Thrifty Food Plan for household sizes 1-4 in 2000 are shown below. For comparison purposes, they are also show in dollars/person/day.

\footnotetext{
2 An explanation of how the US measures poverty can be found at http://www.census.gov/hhes/poverty/povdef.html. Poverty thresholds for 2000 can be found at: http://pubdb3.census.gov/macro/032001/pov/new21 000.htm The estimated cost of the Thrift Food Plan in 2000 can be found at: http://www.usda.gov/cnpp/FoodPlans/Updates/foodnov00.pdf
} 
Table 5. US Thrifty Food Plan and Poverty Line, 2000.

\begin{tabular}{cccccc}
\hline & \multicolumn{2}{c}{ Thrifty Food Plan } & & \multicolumn{2}{c}{ Poverty Line } \\
\cline { 2 - 3 } \cline { 5 - 6 } Household size & weekly & $\begin{array}{c}\text { per person } \\
\text { per day }\end{array}$ & & annual & $\begin{array}{c}\text { per person } \\
\text { per day }\end{array}$ \\
1 & $\$ 32.88^{1}$ & $\$ 4.70$ & & $\$ 87,942^{2}$ & $\$ 24.09$ \\
3 & $\$ 66.33^{3}$ & $\$ 4.74$ & & $\$ 11,239$ & $\$ 15.40$ \\
4 & $\$ 76.34^{4}$ & $\$ 3.64$ & & $\$ 13,738$ & $\$ 12.55$ \\
Average & $\$ 97.3^{5}$ & $\$ 3.48$ & & $\$ 17,603$ & $\$ 12.06$ \\
\hline
\end{tabular}

Source: Thrifty Food Plan reported by the US Department of Agriculture. Poverty lines reported by the US Census Bureau.

${ }^{1}$ Average of adult male and adult female plus 20 percent adjustment for single person household.

${ }^{2}$ The Census Bureau reports poverty thresholds by household size adjusted for the age of the head (elderly or not) and for the number of children in the family. These poverty lines are the averages for household size over age-composition categories.

${ }^{3}$ Adult male plus adult female plus 10 percent adjustment for household size.

${ }^{4}$ Adult female plus two children, ages 3-5 and 9-11, plus 5 percent adjustment for household size.

${ }^{5}$ Adult male plus adult female plus two children, ages 3-5 and 9-11. The TFP is calculated on the base of a family of four, so the adjustments for other household sizes are meant to make them equivalent.

${ }^{6}$ Average calculated usuing the household composition captured by the Current Population Survery (March Supplement, 2000).

Canada does not define an official poverty line. Statistics Canada does, however, define several measures of low income. ${ }^{3}$ One is a relative measure (the Low Income Measure), defined as 50 percent of median income, discussed below. The Low Income Cut-offs, most commonly used in Canada as an indicator of poverty, are defined in terms of the proportion of income that families spend on the basic needs of food, clothing, transportation and shelter. Low income is defined as having twenty percentage points less of income to spend on non-basic needs. In 2000, low income was defined at the level at which families spent 54.7 percent of their income on basic needs. Canada estimates low income levels for rural areas and for urban places of various sizes. The low-income cutoffs for rural areas and for medium size cities (population 100,000 to

\footnotetext{
${ }^{3}$ Canada's low income guidelines are described at: http://www.statcan.ca/cgibin/downpub/listpub.cgi?catno=75F0002MIE2004002
} 
499,000) are show below, expressed as annual income in Canadian dollars, and in \$US/person/day at PPP.

Table 6. Canada Low Income Cut-offs, 2000.

\begin{tabular}{cccccc}
\hline & \multicolumn{2}{c}{ Cities $100-400,000$} & & \multicolumn{2}{c}{ Rural areas } \\
\cline { 2 - 3 } \cline { 5 - 6 } Household size & Annual $\$ C$ & $\begin{array}{c}\text { per person } \\
\text { per day }\end{array}$ & & Annual $\$ C$ & $\begin{array}{c}\text { per person } \\
\text { per day }\end{array}$ \\
1 & $\$ 15,757$ & $\$ 35.68$ & & $\$ 12,696$ & $\$ 28.75$ \\
2 & $\$ 19,697$ & $\$ 22.30$ & & $\$ 15,870$ & $\$ 17.97$ \\
3 & $\$ 24,497$ & $\$ 18.49$ & & $\$ 19,738$ & $\$ 14.90$ \\
4 & $\$ 29,653$ & $\$ 16.79$ & & & \\
& & & & & \\
\hline
\end{tabular}

Source: Statistics Canada.

Canada has also estimated the cost of the market basket of basic needs, which it uses as an alternative approach to measuring low income. One component of this market basket is an estimate of the cost of food. These costs are estimated separately for provinces and different community sizes. The estimated cost of food for a four-person family in a medium size city in Quebec is \$C 6,064. In \$US @PPP, this is equivalent to $\$ 3.43 /$ person/day_reassuringly similar to both the US and the Mexican lines.

These official poverty lines express each country's effort to define absolute poverty in its own context. They are meant to represent what it costs in each country to lead a minimally decent life, and they are meant to be constant over time so that progress or failure in reducing absolute poverty can be gauged. We use them in this paper to examine the relationship of poverty and place within countries, primarily because much of the data we have for this purpose uses these lines.

Comparable absolute poverty. Although the national poverty lines have a logic and a use for measuring poverty within each country, to examine poverty in North America we need a poverty measure or measures that can be used across countries. We use two approaches: absolute and relative. As our absolute poverty measures, we use the Mexican food poverty and basic needs poverty lines for urban areas expressed in US dollars at PPP. As shown above, that line is $\$ 6.76$ per person per day, or $\$ 9,870$ for a family of four - a little more than half the US official poverty line and about 40 percent of the Canadian low income cut-off for a family of four.

We looked for an absolute poverty measure for North America to use across all three countries because we believe that purely relative measures, or even allegedly absolute measures defined for each country can lead us to misleading conclusions about the incidence, character and location of poverty in North America. It is simply not the 
case that poverty is an equally serious matter in Mexico and the United States, as the relative poverty measures could lead us to believe. A comparable absolute measure allows us to recognize this and explore its implications.

It is interesting to note that the estimated cost of the basic food basket, when expressed in dollars adjusted for purchasing power parity, is about the same in Mexico, the United States and Canada--\$3.40/person/day in urban Mexico, \$3.70/person/day for a four person family in the United States and \$3.40 for a four person family in urban Quebec. This suggests to us that the components and cost of a basic nutritious diet are being estimated in about the same way in Mexico, the United States and Canada, and that the PPP adjustments in fact work to make the costs of the basic basket equivalent.

The basic needs poverty line in Mexico is about twice the food poverty line, reflecting the fact that families need an amount about equivalent to what they spend on food to meet their needs for shelter, clothing, health, education and transportation at a very basic level. In the US, the official poverty line is about 3.5 times the food poverty line as expressed by the thrifty food plan. In Canada, the low-income cut-off is almost 5 times the estimated cost of a food basket. This suggests that families in the US and Canada are perceived to need more in the way of non-food consumption to lead a decent life, but in our view that reflects a conception of needs that is more relative than absolute. The PPP adjustments take care of differences in the costs of the same basket of goods. Fewer persons per room, central heating and air-conditioning, functioning automobiles and various household appliances may indeed be basic in the United States and Canada, but it is still worth asking how many people in the US and Canada are living on an income that allows them to purchase only what would be considered basic in Mexico. Using the Mexican poverty line as one measure of poverty across all three countries allows us to estimate how many people in North America as a whole live in the conditions of material scarcity that characterize the lives of much of the Mexican population.

Relative poverty. We also, however, look at relative poverty. The logic of this approach is the perception that what it takes to lead a decent life is in fact defined by the standards of living in the community. Money income is a means to ends, one of which is simple material survival but another of which is inclusion and participation in the mainstream society in which one lives. To be a full member of the society requires being able to purchase goods and live in conditions that characterize the normal life of the community. To get at this notion, relative income is the appropriate measure.

We use as our relative poverty measure half the median income for the country in which one lives. This measure is used widely in OECD countries, and using it allows us to estimate poverty and its characteristics using the data sets for Canada, Mexico and the US of the Luxembourg Income Studies. ${ }^{4}$ Whether one's country, rather than one's city, state or region is the most relevant reference group for people as they define their own relationship to the society is, of course, debatable. But it does seem to be the case that when people in many countries are surveyed as to what it costs to live a decent life they

${ }^{4}$ http://www.lisproject.org 
tend to report a figure close to half the median income. This has become a conventional poverty measure and we employ it here.

In the US in 2000 , the relative poverty line for a family of four was $\$ 32,690$, or $\$ 22.39 /$ person/day. In Canada in 2001, the relative poverty line for a family of four was \$25,570 (\$US@PPP), or \$17.51/person/day. The same figures for Mexico in 2000 were \$4,285 (\$US@PPP) and \$2.93, respectively.

Mexico is the only country whose relative poverty line is lower than its officially defined absolute poverty thresholds (see Table 2). This shows that differences in income distributions between Mexico and its NAFTA counterparts are much larger than differences in absolute poverty thresholds. In other words, Canada and the U.S. have defined lower absolute poverty lines relative to their income distributions than Mexico, as we will see in more detail later.

Income Distributions and Poverty Lines. Figure 5 illustrates the relationships between the income distributions and poverty incidence for Mexico and the United States in 2000. It shows the density curves of the distribution of monetary income (international dollars per day per person), this is, the share of population at each level of income represented on a logarithmic scale. The figure also plots vertical lines depicting the official poverty lines of these countries, as well as the food and basic needs poverty thresholds. The areas under the curves represent the proportion of each population that is defined as poor by the various definitions. 


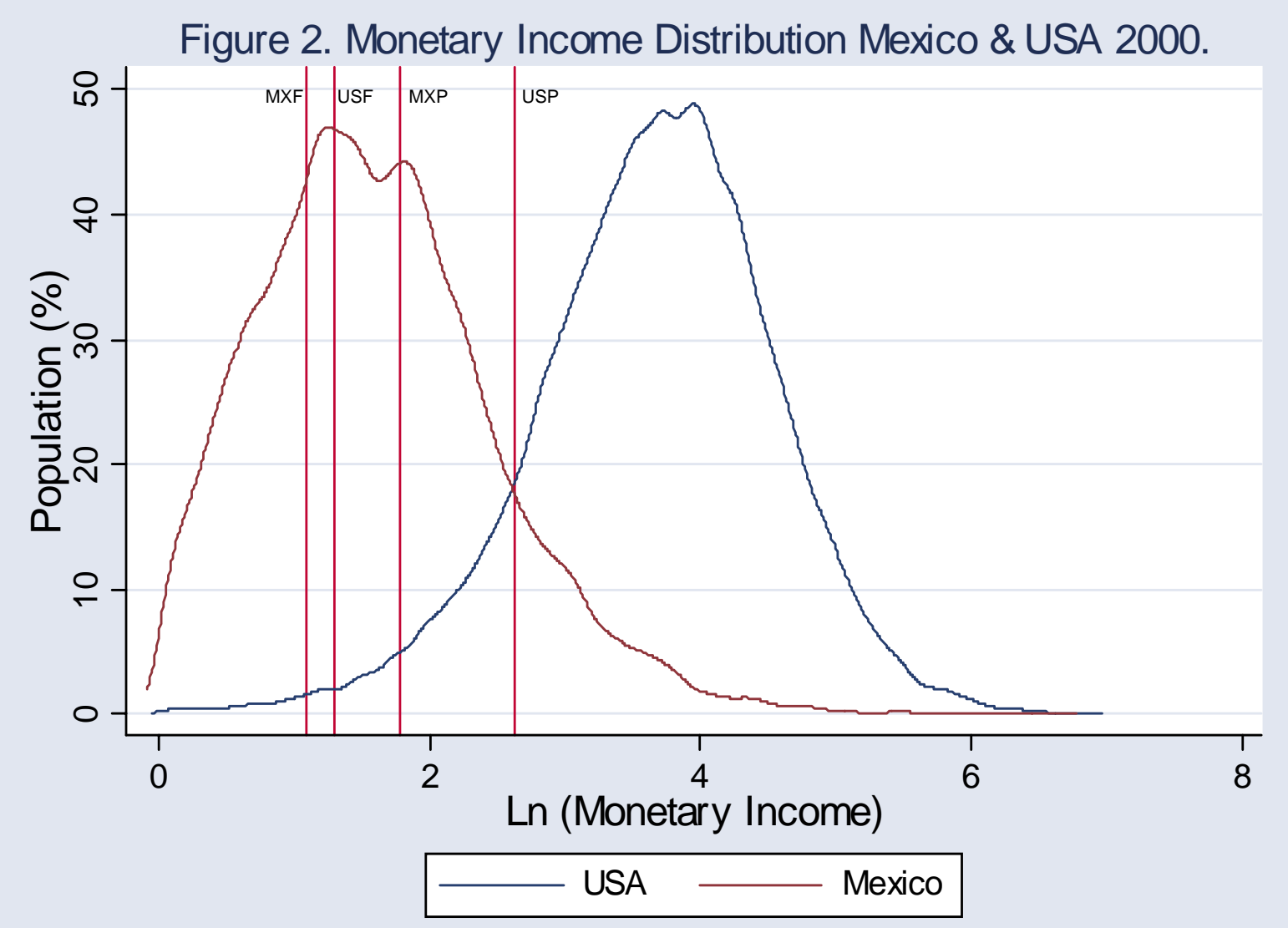

Source: Author's calculations using ENIGH 2000 and CPS March Supplement 2001.

The income distribution differs greatly between Mexico and the United States. The overlap is minimal and the U.S. shows a more prominent middle class. Average daily per-capita income is estimated to be 6.5 times greater in the United States than in Mexico: \$57.0 and \$8.7, respectively (see Table 7). ${ }^{5}$ The median income ratio is even higher (8.7 times). Greater inequality in Mexico than in the U.S. is also illustrated by the distance between the mean and median incomes in each country.

${ }^{5}$ Income figures come from household surveys in both countries. Numbers do not add to income statistics calculated using GDP data. The underreport of income in household surveys seems to be worse in the case of Mexico. 
Table 7. Population Distribution of Monetary Household Income Per Peson Per Day and Poverty Thresholds. Mexico and United States, 2000.

\begin{tabular}{|c|c|c|}
\hline & $\begin{array}{c}\text { Mexico } \\
\text { (US@PPP) }\end{array}$ & US \\
\hline Mean & $\$ 8.7$ & $\$ 57.0$ \\
\hline Median & $\$ 4.8$ & $\$ 41.8$ \\
\hline $50 \%$ Median & $\$ 2.4$ & $\$ 20.9$ \\
\hline Official Poverty Threshold (OPT) ${ }^{1}$ & $\$ 5.9$ & $\$ 13.8$ \\
\hline OPT \% of Median & $123 \%$ & $33 \%$ \\
\hline
\end{tabular}

Sources: Encuesta Nacional de Ingreso y Gasto de los Hogares (ENIGH-2000) and Current Population Survey (CPS March Supplement 2000).

${ }^{1}$ Mexico is a national weighted average using the rural-urban population composition captured by ENIGH 2000. The U.S. is a national weighted average taking into account the household composition captured by CPS 2000.

In Mexico and the United States food-budget standards are calculated independent of income distribution data. The components of a basic nutritious diet are being defined in about the same way in Mexico and the United States. The U.S. official poverty line is much higher than the Mexican one, but it is not as high as income differences. In spite of the fact that income is more than 6 times higher in the U.S. than in Mexico, the U.S. official poverty threshold is only 2.3 higher than the Mexican one. As seen in Table 7, the official poverty threshold in the United States is only 33 percent of the median income, while in Mexico is 23 percent above median income.

These comparisons emphasize the fact that there is no one "right" way to define poverty, and that both "absolute" and relative measures are useful in understanding the circumstances in which people live in different countries. We are reluctant to conclude that the official Mexican poverty line is too high, since it was constructed to represent what is perceived as a decent standard of living. It is also not unreasonable to conclude that half the country is poor using this standard, and to aspire to raise the overall standard of living such that fewer Mexicans fall below this poverty line. At the same time, in thinking about how to target public resources on the most needy, it makes a good deal of sense to use a lower poverty line, either the food poverty line or the line defined by relative income.

\section{Poverty Incidence using Different Poverty Measures}

Table 8 shows the incidence of poverty in 2000 in Canada, Mexico and the US using national poverty lines, the Mexican poverty lines applied to the US as well as Mexico and vice versa, and the relative income poverty line. The Canada data come 
from published Statistics Canada and Luxemburg Income Survey data tables. For Mexico and the United States, we estimated poverty rates from household survey data. The estimates are sensitive not only to the choice of poverty lines, but to the treatment of households of different sizes and to the quality of the underlying survey data. In the US, income appears to be underreported at both the very high end, which is irrelevant to poverty rates, and at the very low end, which may lead to overestimates of poverty as measured by the Mexico lines (Weinberg, 2004). In Mexico, problems of underreporting seem to be more widespread, and may lead to overestimates of poverty however measured. (Szekely et. al., 2000) The seriousness of this problem can be grasped by comparing the estimate of per capita GDP in Table 1 with mean per capita income estimated from survey data in Figure 2 and Table 9. For the US the ratio of the estimates is about .58, with most of the discrepancy due to categories of income that are included in GDP but not in household income measured by the survey, and much of the rest due to underreporting by the rich. In Mexico the ratio is .about .33. If household income in the bottom half of the income distribution is underestimated by a substantial amount, then poverty rates could be overestimated by an analogous amount. The lack of adjustments for household size in Mexico is another way in which the estimates for the three countries are not comparable, with poverty in Mexico being relatively overestimated. Household sizes in Mexico are relatively large, and most poverty scholars agree that there are indeed some economies of scale in household spending. These are taken into account in the poverty measures of the US and Canada, but not in Mexico, where they are probably more important.

So we should be very cautious about drawing conclusions from the comparisons. Nonetheless, they are quite striking. With a poverty rate of 11.3 percent, the United States has the lowest official incidence of poverty in North America, followed by Canada with 14.6 percent of its population living below its officially defined poverty line. In Mexico, about one of every two inhabitants is officially considered poor. The deprived economic panorama of Mexico does not change with our comparable poverty measures. Mexico has by far the highest level of absolute poverty using our comparable measure. Even if poverty in Mexico is overestimated by a factor of two, the differences between Mexico and the other two countries are very large.

When the official US poverty line is used as the measure of poverty in the three countries, Mexico, as would be expected, is shown to have an extremely high incidence of poverty. Interestingly, Canada has a lower poverty rate than the US using the common definition of poverty, even though Canada has lower per capita income. This comparison shows the importance of income inequality in determining poverty: Canada's more equal income distribution yields a lower poverty rate. Canada also has an incidence of relative poverty that is well below that of either Mexico or the United States, again reflecting its greater equality of income. About one of every four Mexicans can be classified as poor using relative standards of poverty, a figure closer to food poverty rates than to basic needs poverty rates in the country. 
Table 8. Incidence of Poverty Using Different Poverty Measures, Canada, Mexico and U.S., 2000.

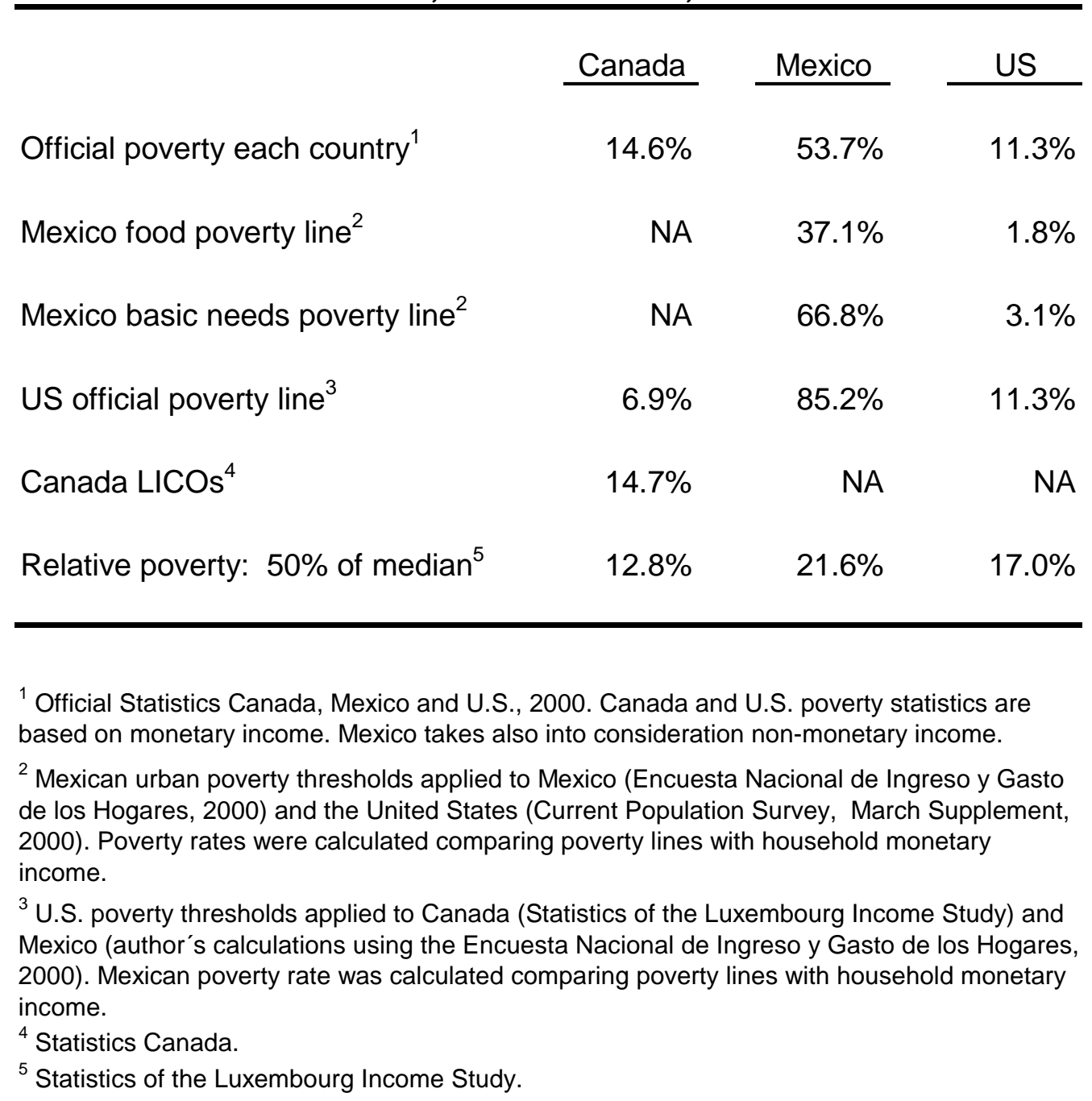

The poverty rates for three countries are a striking illustration of the fact, documented in many cross-country studies, of the relationship between the poverty rate, the overall level of development as measured by per capita income, and the extent of inequality. They surely suggest the importance of an overall development strategy as key to poverty reduction in Mexico.

\section{Poverty and Place within Countries}

If the level of overall economic development is so crucial, as suggested by the differences in poverty incidence and their relationship to overall levels and growth rates of GDP in Mexico, the US and Canada, then we might expect poverty within countries to be related to the overall levels of development of states or provinces. The extent to 
which this relationship holds, or does not hold, may help us understand both the phenomenon of poverty within each country, and may also help us understand the dramatic differences between countries. In this section we explore that relationship.

Poverty and place in the US. Poverty rates in the United States vary by place, ranging in 1999 from about 20 percent in Mississippi, Louisiana and DC to less than 8 percent in Connecticut, New Hampshire and Minnesota. The variation in poverty rates is related to the overall level of per capita income in the states. The figure, below, shows that relationship. ${ }^{6}$

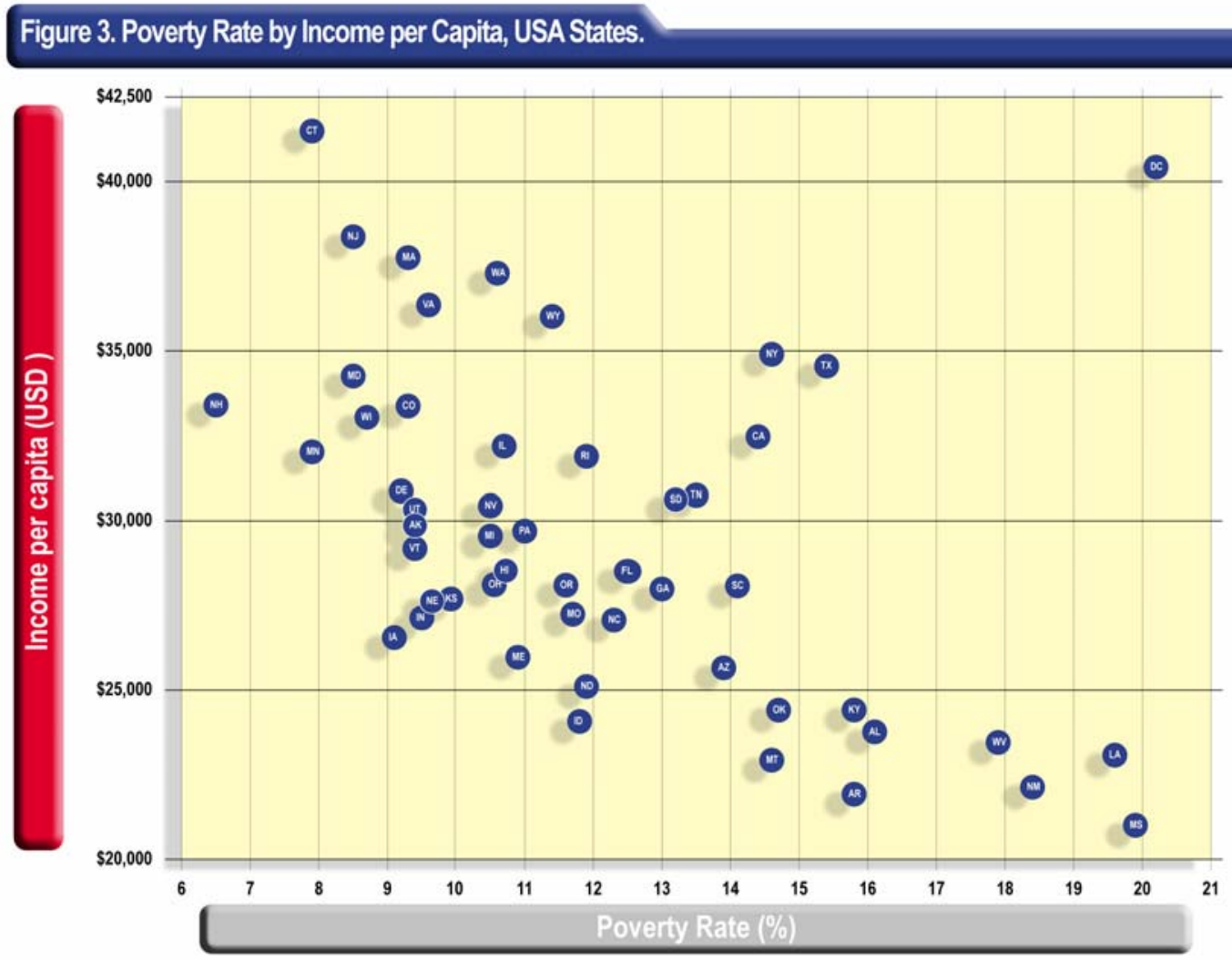

The relationship is by no means perfect: Some states, like Iowa, Nebraska and Utah, have both relatively low per capita income and low poverty rates; and other states, most notably the District of Columbia, but also California and New York, have both high per capita income and high poverty rates - in the case of DC, very high indeed.

Nonetheless the basic relationship between the level of development and poverty rates is relatively robust.

\footnotetext{
${ }^{6}$ All the tables and graphs in this section are constructed from US Census data on income and poverty rates by states, available on the census website. http://factfinder.census.gov/servlet/GCTTable?_bm=y\&geo_id=01000US\&-_box_head_nbr=GCT-P14\&-ds_name=DEC_2000_SF3_U\&-_lang=en\&-format=US9\&-_sse $=$ on
} 
We need to ask, though, how important this relationship is for explaining patterns of poverty in the United States and for guiding policy. Should we conclude, as development economists conclude when they look at poverty and economic development across countries, that per capita income differences among states or other political entities are essentially the whole story of poverty? Should we conclude, as they do, that attention to development will solve poverty problems? There are three ways of approaching the problem that suggest that this conclusion would not be correct.

A first approach is to look at the relationship between the number of poor in a state and its per capita income. The largest number of poor in any state is found in California, which ranks 14/51 in per capita income. Half the poor in the US are found in eight states: California, Texas, New York, Florida, Pennsylvania, Illinois, Ohio and Georgia. With the exception of Texas, which ranks 33 in per capita income, all these states are in the top half of the per capita income distribution; indeed six of the eight are in the top quarter of the per capita income distribution. This finding reflects both a high level of inequality and thus relatively high poverty rates in rich states like New York and California. It also reflects the fact that many of the richer states are quite large, so that even with average or below poverty rates-as in Illinois and Michigan-they are home to large numbers of poor.

Another way of looking at these relationships is to ask what proportion of the poor live in poor states as defined by per capita income. For this calculation we ranked the states by per capita income, and then examined the group of low income states whose cumulative population numbers came to about a quarter of the country. In the US this procedure identified twenty states, ranging from Mississippi with a per capita income of $\$ 15,853$ to Iowa with a per capita income of $\$ 19,674 .^{7}$ (The US average in 2000 was $\$ 21,587$.) The group includes states in the deep south, Maine, and some mountain, plains and mid-western states, for example, the Dakotas and New Mexico. These twenty US states included 24 percent of the population and 29 percent of the poor. In other words, the percentage of the poor living in poor states is not much higher than the overall percentage of the population (or of the non-poor) living in those states. It is also worth noting that while 29 percent of the US poor live in these poor states, 71 percent do not.

A third approach is to examine two important historical divisions in income and poverty and ask what has happened to them over time: between rural and urban areas, and between the south and the rest of the country.

In 1959, the first year for which the Census Bureau reports poverty data, the poverty rate for rural areas was 33 percent, compared to an overall national poverty rate of 22 percent. Residents of rural areas, made up 37 percent of the population and 55 percent of the poor. By 2003, the poverty rate for rural areas was 14 percent, compared

\footnotetext{
${ }^{7}$ The twenty states, in increasing order of per capita income, are: Mississippi, West Virginia, Arkansas, Louisiana, Montana, New Mexico, South Dakota, Oklahoma, North Dakota, Idaho, Kentucky, Utah, Alabama, South Carolina, Wyoming, Tennessee, Maine, Nebraska, Texas and Iowa.
} 
to an overall national rate of 12 percent. Eighteen percent of the population and 21 percent of the poor lived in rural areas.

The seventeen states of the south have historically been more rural and more poor than the rest of the country. ${ }^{8}$ In 1959 , the poverty rate in the south (35.4 percent) was more than half again the poverty rate in the nation as a whole (22.4. percent). Thirty-one percent of the population but 48 percent of the poor lived in the south. In 2003 the poverty rate in the south was closer to that of the nation: $15.3 \%$ in the south; $11.1 \%$ in the nation, and 41 percent of the poor lived in the south compared to 36 percent of the population.

This convergence in poverty rates reflects urbanization, convergence between rural and urban areas and convergence between south and north in per capital income, a process which can be documented for a longer period than for poverty rates. In 1940, per capita income in the south was about 68 percent of income in the country as a whole, in 1960 it was 77 percent and in 2000 per capita income in the south was 91 percent of income in the country as a whole. The process by which the southern economy became integrated into the national economy may offer interesting insights into the economic futures of Mexico and the US, a topic which we hope to develop in later papers.

In explaining contemporary poverty in the US, in short, we do not get very far with an emphasis on variations in the levels of development among states. Interestingly, variations among metropolitan areas in overall level of development do not explain very much either. ${ }^{9}$ Some isolated very poor areas persist, most notably Native American reservations, and some very poor areas along the Mexican border. But in the contemporary United States, poverty is more strongly related to household composition and to race and ethnicity than it is to geography.

Poverty and place in Mexico. The story of poverty and place in Mexico is somewhat different. As in the US, poverty rates vary by state, with the low income states of the south having the highest poverty rates. The figure below shows the relationship between food poverty rates and per capita income by state. (Since basic needs poverty is so widespread, affecting 60 percent of the population, we expect that it would be widely distributed geographically. The more stringent conception of poverty is more likely to be driven by overall levels of development.)

\footnotetext{
${ }^{8}$ The states are South Atlantic: Delaware, District of Columbia, Florida, Georgia, Maryland, North Carolina, South Carolina, Virginia and West Virginia; East South Central: Alabama, Kentucky, Mississippi and Tennessee; West South Central: Arkansas, Louisiana, Oklahoma and Texas.

${ }^{9}$ Following the same procedure as for states, we can sort metropolitan areas by per capita income in 1999. We identified 177 metropolitan areas from McAllen TX with a per capita income of \$9899 to Knoxville TN with a per capita income of $\$ 20,538$. These poor metropolitan areas include 25 percent of the metropolitan population and 31 percent of the metropolitan poor. Data from the Census: http://factfinder.census.gov/servlet/GCTTable?_bm=y\&-geo_id=\&-ds_name=DEC_2000_SF3_U\&_caller=geoselect\&-_lang=en\&-redoLog=false \&-format=US-10\&mt_name=DEC_2000_SF3_U_GCTP14_US9
} 
Figure 4. Poverty Rate by Income per Capita, Mexican States.

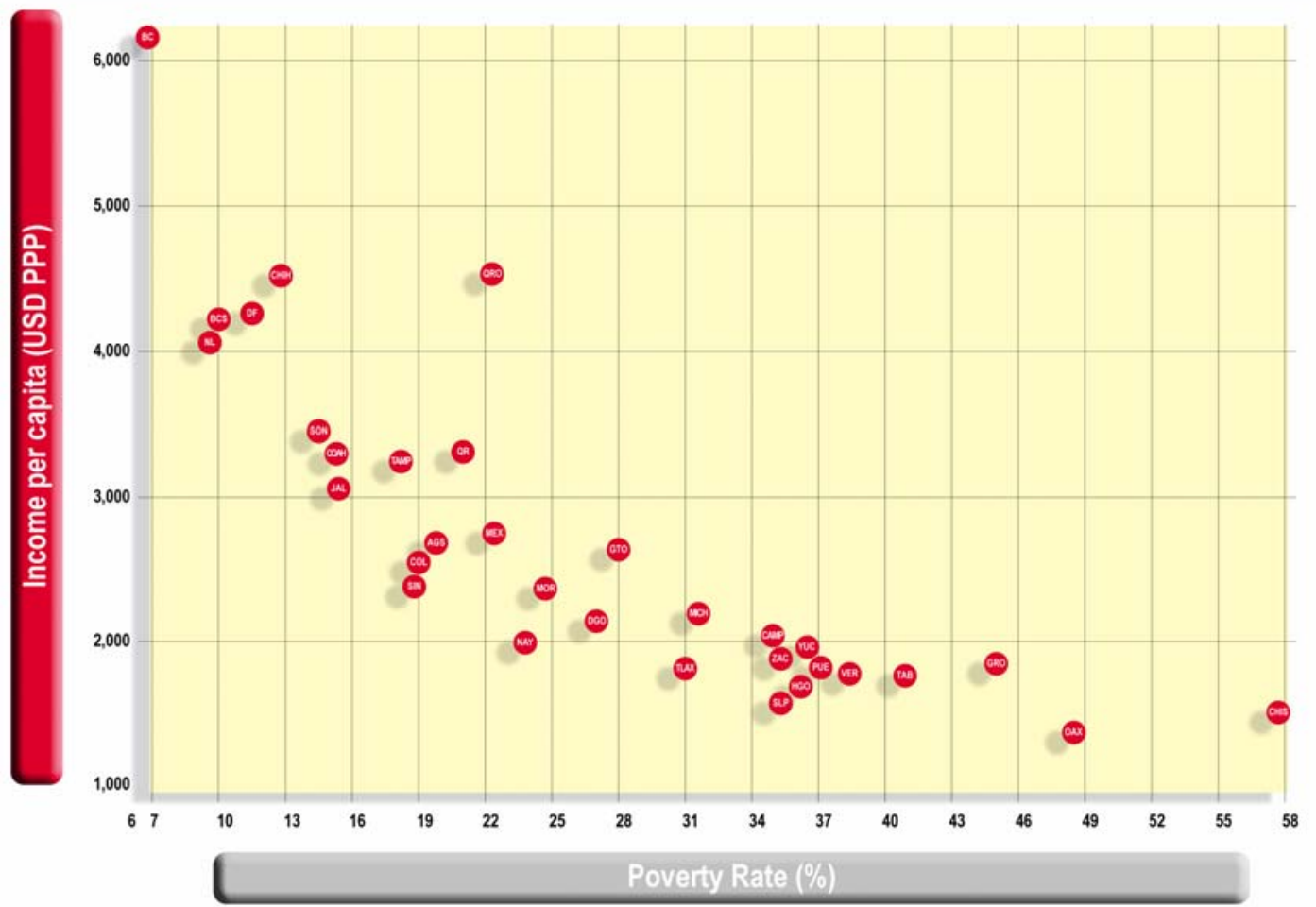

In Mexico, however, unlike the US, numbers of poor are also related to per capita income by states. The largest number of poor in Mexico live in Veracurz, which ranks 26/32 in per capita income. The next largest number of poor are in Chiapas, which ranks second last in per capita income. Following the same procedures as for the US, we ranked Mexican states by per capita income and identified seven low income states, with per capita income ranging from \$1382 in Oaxaca to \$1855 in Guerrero. ${ }^{10}$ (Here the income data are from household surveys.) Most though not all of these states are in the south. They are home to 23 percent of the Mexican population and 38 percent of the food poor.

In Mexico, then, in contrast to the US, the poor are quite concentrated geographically in states with low levels of economic development, giving credence to an argument that local development plus migration are important strategies for addressing poverty. At the same time, it is worth noting that while 38 percent of the very poor live in the eight poor states, 62 percent of the poor do not. The relationship between number of per and per capita income is by no means perfect. For example, the third largest number of poor are in the state of Mexico, which ranks 18/32 in per capita income and

\footnotetext{
${ }^{10}$ The eight states, in increasing order of per capita income, are: Chiapas, Oaxaca, Zacatecas, Tlaxcala, Michoacan, Guerrero, Veracruz and Nayarit.
} 
has a moderate poverty rate, but is also the most populous state. Thus in Mexico, as in the US, large numbers of the poor live in relatively rich states. The geographical concentration of the poor is likely to decrease over time, as rural to urban and south to north migration continues. Thus it is important for Mexico to focus on urban poverty, and poverty that exists alongside overall wealth, as well as on the low development levels of the southern states.

Poverty and place in Canada. Canada is a somewhat different story, as the figure below shows. The province with the highest GDP per capita, Alberta (with considerable oil wealth) has a poverty rate that is not much different from much less wealthy provinces. Alberta aside, there appears to be rather little relationship between poverty rates and overall development level.
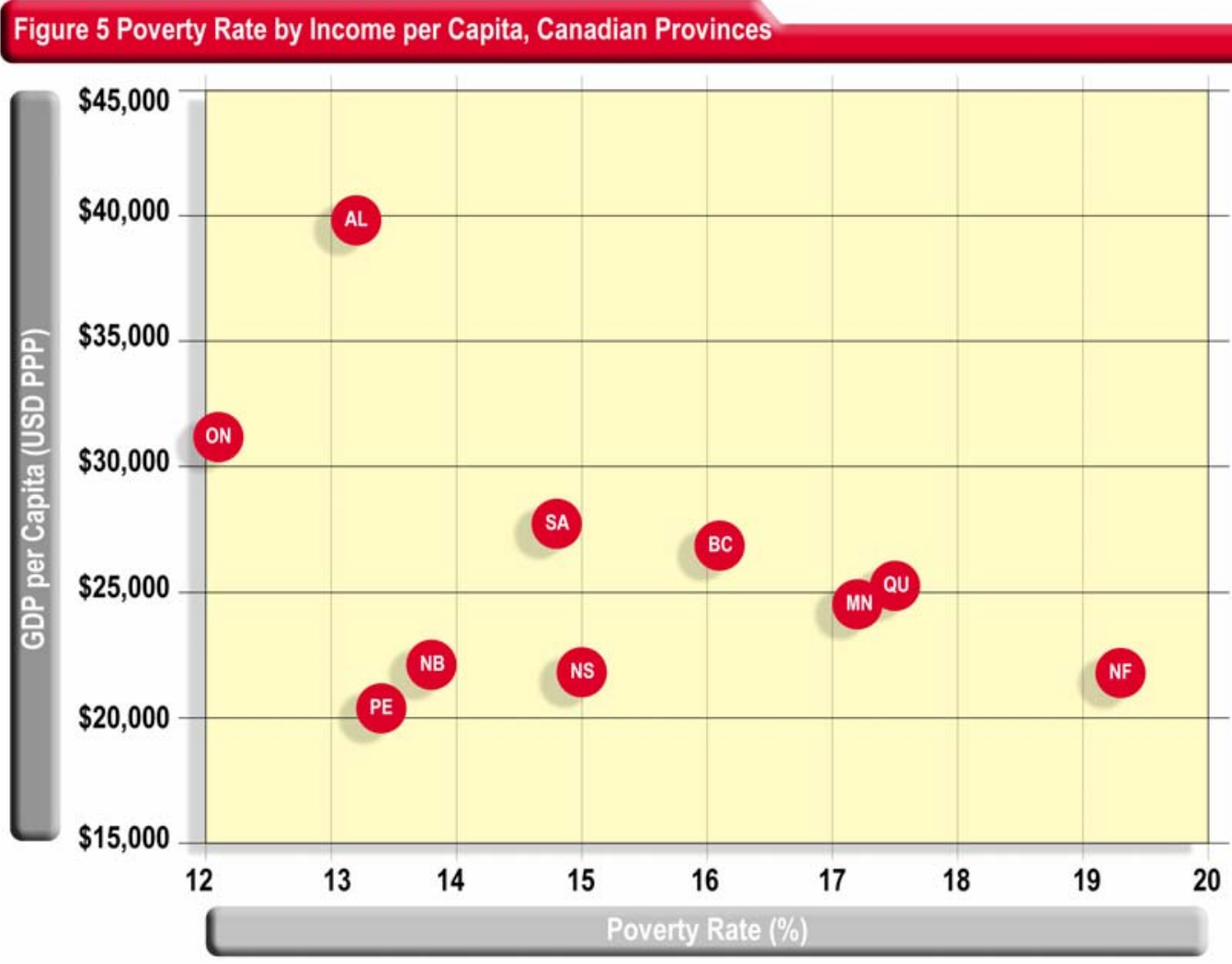

Canada is composed of eleven provinces plus the Yukon, the Northwest Territories and Nunavit. Two provinces, Ontario and Quebec, contain more than half the population. The four poorest provinces, Prince Edward Island, New Brunswick, Nova Scotia and Manitoba contain only 10 percent of the population and ten percent of the poor. (The poverty measure is the official Canadian low income cut-off.) Quebec is the next poorest; adding if to the list brings the percent of the population to 34 and the percent of the poor to 39. Alberta, as noted earlier enjoys great oil wealth, as do the very sparsely populated northern territories. All of this means that the relationships of poverty 
and place in Canada are more difficult to summarize and less interesting that those in the US and Mexico.

\section{Poverty and Place between Countries}

Within the countries of North America, in summary, place is not an important determinant of poverty in the United States or Canada, but is a moderate determinant in Mexico, where the lower level of development in the southern states is associated with much higher poverty rates and a concentration of the poor. In some ways, the south of Mexico looks similar to the southern states of the US before the process of urbanization and integration into the national economy began. And there are some indications in Mexico that migration from rural to urban areas, and from south to north may be blurring some of the differences even there.

But when we look at the countries within North America, the strength of the relationship between poverty and place is stunning. Table 8 (above) showed poverty rates using a variety of ways of defining poverty:

Obviously one can argue about what the appropriate definition of poverty is for each country and for the region. But putting aside that discussion, it is possible to specify an income cutoff expressed in a common purchasing-power-parity adjusted currency, and to see what proportion of people in each country and in the region as a whole fall below that cutoff. That is what we did in the middle rows of Table 8. And it is clear that with whatever common cutoff we use, of those who fall below the line, about three quarters or more live in Mexico.

This is not surprising, given the differences in per capita GDP that we documented in Table 1 and Figure 1. But the disparities ought to be shocking, and the patterns of convergence or more accurately lack thereof shown in Figure 1 ought to be extremely disturbing. As Figure 1 showed, since the early 1980s, per capita GDP in the United States and Mexico has actually diverged rather than converged.

Hispanic communities. Is this disparity about being Mexican, or about living in Mexico? About 13 of the population of the US identified itself to census takers as Hispanic. About two thirds of that number, or about 9 percent of the US population identified itself as Hispanic and of Mexican origin. We have some information that allows us to compare this Mexican-American population with the larger US population, and to ask whether poverty and low income is more associated with being Mexican than with living in Mexico.

We first look at poverty rates. In 1999, the US poverty rate was 11.9 percent. ${ }^{11}$ For comparison we can look at the poverty rate for Mexican Americans, which was 24.1

\footnotetext{
${ }^{11}$ This number and the numbers of Mexican-Americans and for states are from the CPS: http://www.census.gov/population/socdemo/hispanic/ppl-165/tab14-2.pdf
} 
percent. The poverty rate in the border states of Arizona, California, New Mexico and Texas was 14.3 percent. However, the poverty rate for the Texas border communities with high proportions (75+) Hispanic (McAllen, Brownsville, Laredo, and El Paso) was 30.2 percent. $^{12}$

The poverty rate for Mexican origin Hispanics in the US is thus about twice the overall US poverty rate, and higher even than that in the border communities. A poverty rate of 30 percent, using the US official poverty line, is shamefully high for a group within US borders. But our best estimate of what the poverty rate in Mexico would be if we used the US poverty line as the poverty definition was 82 percent. Even using the much lower Mexican basic needs poverty line, the poverty rate in Mexico was 60 percent, more than twice the poverty rate for Mexican communities in the US with their poverty measured by the US line.

We can also make comparisons across the border by looking at per capita household income, adjusted for purchasing power parity. These are suggestive numbers, from household survey data in the US and Mexico. They are not adjusted for underreporting, which appears to be a quite serious problem in Mexico.

Table 9. Per capita income 1999/2000.

$\begin{array}{lr}\text { United States, nation }^{1} & \$ 21,587 \\ \text { US border states }^{2} & 21,331 \\ \text { US Hispanics, all states }^{3} & 11,621 \\ \text { Texas border communities }^{4} & 11,539 \\ \text { Mexican border states } & 4,140 \\ \text { Mexico, nation } & 2,772 \\ \text { Mexico, southern states }^{5} & 1,574\end{array}$

\footnotetext{
${ }^{1}$ Arizona, California, New Mexico and Texas.

${ }^{2}$ This number is for all Hispanics, of whom Hispanics of Mexican origin make up about two thirds. The next largest group of Hispanics are Puerto Ricans, who have family incomes and poverty rates slightly lower than those for Mexicans.

${ }^{3}$ As above: McAllen, Laredo, Brownsville and EI Paso TX.

${ }^{4}$ Baja California, Sonora, Chihuahua, Coahuila, Nuevo Leon, Tamaulipas. These are per capita income numbers calculated from household surveys, and expressed in \$US, PPP adjusted. The amount of income captured by the household surveys is bout 37 percent of GDP and about half of household final consumption as calculated from national accounts. They obviously need to be adjusted upward to be realistic, perhaps by as much as 100 percent.

${ }^{5}$ Chiapas, Guerrero, Oaxaca.
}

\footnotetext{
${ }^{12}$ This number is not completely comparable to the others, since it comes from the Census rather than the CPS. Poverty rates collected by the Census tend to be higher than those collected by the CPS, since the CPS appears to do a better job of collecting income information. The US poverty rate in 1999, as calculated from Census data, was $12.4 \%$. Data reference in footnote 7 , above.
} 
These numbers suggest that per capita income of Hispanics in the US is four times that of Mexicans, and 2.8 times that of Mexicans in the relatively rich Mexican states that border the US. Even if the Mexican income data is underreported by a factor of two, it appears that the per capita income of the average Hispanic in the US is twice that of the average Mexican and half again as much as the average Mexican in the border states. They thus strongly reinforce the notion that poverty is related to average per capita income, and that income is strongly influenced by the presence of the Rio Grande, or by the economic, social and political features unique to one or the other side of the river.

\section{Poverty and People}

In the US and Canada, as we have shown, poverty is not strongly related to place. What, then, are the non place-based characteristics of the poor than might help us understand and explain poverty? There are two dramatic stories to be told: a story about race and ethnicity; and a story about family and household composition. In this section, we will look first at data on family and household composition in the US and Mexico. We will then look at some data on race and ethnicity in both countries.

Household composition. Table 10 shows for Mexico and the United States the distribution of the population by five household types: elderly in all household arrangements; non-elderly unrelated individuals (people living alone or with nonrelatives); non-elderly people, including children, in married couple families; non-elderly people, including children, in female headed families; and people in other household arrangements. The table also shows poverty rates for each group. For Mexico, the poverty line used to estimate poverty is the official food poverty line. For the US, the poverty definition is the official census bureau market-basket definition. ${ }^{13}$

${ }^{13}$ US data from detailed on line tables of the CPS:

http://pubdb3.census.gov/macro/032001/pov/new01_000.htm. We also looked at the data using other poverty definitions. The basic relationships among family types remain the same. 
Table 10. Household Composition and Poverty: US and Mexico, 2000.

\begin{tabular}{|c|c|c|c|c|}
\hline & \multicolumn{2}{|c|}{ Mexico $^{1}$} & \multicolumn{2}{|c|}{ United States $^{2}$} \\
\hline & $\begin{array}{l}\text { Population } \\
\text { Distribution }\end{array}$ & $\begin{array}{l}\text { Poverty } \\
\text { Rate }\end{array}$ & $\begin{array}{l}\text { Population } \\
\text { Distribution }\end{array}$ & $\begin{array}{l}\text { Poverty } \\
\text { Rate }\end{array}$ \\
\hline Elderly & $5.4 \%$ & $21.9 \%$ & $12.0 \%$ & $10.2 \%$ \\
\hline Non-elderly unrelated individuals & $1.3 \%$ & $5.3 \%$ & $12.5 \%$ & $18.3 \%$ \\
\hline Non-elderly in married couple families & $78.4 \%$ & $25.6 \%$ & $58.5 \%$ & $5.8 \%$ \\
\hline Non-elderly in female headed families & $11.9 \%$ & $19.0 \%$ & $12.6 \%$ & $29.2 \%$ \\
\hline Other & $3.0 \%$ & $18.4 \%$ & $4.4 \%$ & $15.5 \%$ \\
\hline Total & $100.0 \%$ & $24.1 \%$ & $100.0 \%$ & $11.3 \%$ \\
\hline
\end{tabular}

\footnotetext{
${ }^{1}$ Author's calculations based on Mexican Population Census 2000 and poverty rates estimated by Cortés, Rodríguez y Zenteno (2004).

${ }^{2}$ On-line published data from the US Census Bureau.
}

Family and household composition is clearly very different in the US and Mexico. Poverty rates are also very different for household composition types in the US and Mexico.

The United States has larger proportions of the population elderly, much larger proportions living alone or with non-relatives, and slightly larger proportions living in female headed families. The proportion of children living in female headed families (not shown in the table) is considerably larger in the US, 19.5 percent compared to 12 percent in Mexico. (LIS data) The proportion elderly is a result of low fertility rates and high life expectancies that have persisted for some time.

There seems to be a general tendency in the US for people to form independent households when they can afford, or almost afford, to do so. Elderly couples and single elderly men and women are much more likely to live alone than with family. Young adults move out of their parents households and live independently when they are economically independent, or close to being so. Young women, especially African American women, are more likely than in the past to have children and set up their own households when either their own earnings or transfer payments from the government allow them to do so; this tendency is exacerbated when the economic fortunes of the young men they might marry are precarious. Because of these household formation trends, the US has an average household size that is very small, and the diversity of household types illustrated in the tables. This contrasts with household composition in Mexico, where a large majority of the population lives in married couple household, and where average household size is considerably larger.

Many of the independent, non-marital households in the US are also economically vulnerable, as shown by the relatively high poverty rates for unrelated individuals and, 
especially, for those in female headed families. Women and their children living in female headed households now make up about a third of the poor in the US. The women who head these households tend to have relatively low education levels and earning power. And they are supporting their families in most cases with only one adult earner, rather than two, which is the case in most married couple families. The prevalence and poverty of female headed families in the US is disturbingly related to race, which we will explore later in the paper. ${ }^{14}$

In Mexico, in a striking contrast to the US, poverty rates for people living in female headed families are lower than poverty rates for people in married couple families, and poverty rates for unrelated individuals are much lower that those for other household types. Our hypothesis is that in Mexico, independent households are formed only when those forming such households are relatively secure economically. At this point, it seems that relatively small numbers are making the decision that living independently is possible, or worth the increased economic vulnerability that comes from living away from family. We suggest, however, that this is a trend that Mexico will need to watch, in order to avoid the situation in the US, where female headed families are an especially impoverished and vulnerable group.

Race and poverty in the US. Another important part of the story of poverty in the US has to do with race and ethnicity. Poverty rates vary quite dramatically by race, and range from 8 percent for whites to 24 percent for African Americans. Table 11 gives the basic data for the United States in 2003, and shows variations by both race and household type. The poverty measure is the official US poverty line. The data are from on-line published tables from the Current Population Survey. ${ }^{15}$

\footnotetext{
${ }^{14}$ A good collection of pieces on family structure in America is Moynihan et. a. 2004. http://pubdb3.census.gov/macro/032004/pov/new01_100.htm and http://pubdb3.census.gov/macro/032004/pov/new01_100_01.htm
} 
Table 11. Race, Household Composition and Poverty, US, 2003.

\begin{tabular}{|c|c|c|c|c|}
\hline & $\begin{array}{l}\text { Non- } \\
\text { Hispanic } \\
\text { White }\end{array}$ & Black & Asian & Hispanic \\
\hline \multicolumn{5}{|l|}{ Elderly } \\
\hline Percent of group & $14.6 \%$ & $7.8 \%$ & $8.3 \%$ & $5.2 \%$ \\
\hline Poverty rate & $8.0 \%$ & $23.5 \%$ & $14.2 \%$ & $19.5 \%$ \\
\hline \multicolumn{5}{|l|}{$\begin{array}{l}\text { Non-elderly unrelated individuals } \\
\text { and sub-families }\end{array}$} \\
\hline Percent of group & $13.3 \%$ & $14.1 \%$ & $10.9 \%$ & $10.8 \%$ \\
\hline Poverty rate & $18.3 \%$ & $28.9 \%$ & $24.3 \%$ & $28.5 \%$ \\
\hline \multicolumn{5}{|l|}{$\begin{array}{l}\text { Non-elderly persons in married- } \\
\text { couple families }\end{array}$} \\
\hline Percent of group & $61.6 \%$ & $37.1 \%$ & $67.1 \%$ & $59.0 \%$ \\
\hline Poverty rate & $3.8 \%$ & $8.3 \%$ & $7.7 \%$ & $17.0 \%$ \\
\hline \multicolumn{5}{|l|}{$\begin{array}{l}\text { Non-elderly persons in male- } \\
\text { headed families, no spouse }\end{array}$} \\
\hline Percent of group & $3.3 \%$ & $6.0 \%$ & $5.1 \%$ & $7.2 \%$ \\
\hline Poverty rate & $9.9 \%$ & $23.9 \%$ & $12.1 \%$ & $18.6 \%$ \\
\hline \multicolumn{5}{|l|}{$\begin{array}{l}\text { Non-elderly persons in female- } \\
\text { headed families, no spouse }\end{array}$} \\
\hline Percent of group & $8.8 \%$ & $35.0 \%$ & $8.6 \%$ & $17.8 \%$ \\
\hline Poverty rate & $22.3 \%$ & $39.6 \%$ & $25.9 \%$ & $39.3 \%$ \\
\hline Overall poverty rate & $8.2 \%$ & $24.3 \%$ & $11.8 \%$ & $22.5 \%$ \\
\hline Percent of group in population & $62.8 \%$ & $13.1 \%$ & $4.5 \%$ & $14.1 \%$ \\
\hline
\end{tabular}

Source: On-line published data from US Census Bureau.

The second to last row of the table tells the overall story by race:

- The poverty rates for African-Americans and Latinos in the US are almost three times the poverty rates for non-Hispanic whites and twice the poverty rates for Asian-Americans.

The table also compares racial and ethnic groups on selected family structure characteristics. It shows the proportions of the population by race and ethnicity that fall into the five demographic/family structure groups that we examined above-the elderly, non-elderly unrelated individuals, non-elderly persons in married couple families, male headed families and female headed families - and the poverty rates for the groups.

A number of findings are worth noting:

- Poverty rates for the elderly are lower than overall poverty rates for nonHispanic whites, blacks and Hispanics. These low poverty rates for the elderly largely reflect the success of the US Social Security system. 
- Non-elderly unrelated individuals - people who live alone or with nonrelatives - are an important segment of the poor, especially among whites. (Individuals in unrelated subfamilies, a very small group, are included in this category for the sake of completeness.)

- Non-elderly persons living in married couple families have by far the lowest poverty rates of any family structure group, across all racial and ethnic groups. The double-digit poverty rate for Hispanics in married couple families reflects differences in work, earnings and education.

- Poverty rates for male-headed families with no spouse present are higher than poverty rates for married couples, but considerably lower than poverty rates for female headed families in all racial/ethnic groups.

- Female-headed families with no spouse present have much higher poverty rates than other families across racial groups, but with especially dramatic results for African Americans.

- The largest differences between blacks and whites have to do with the much higher proportions of blacks who live in female headed families with children.

- At the same time, poverty rates for blacks and Hispanics are higher than those for non-Hispanic whites and Asians within all family structure groups.

Research that looks for explanations for racial differences in poverty rates and in family formation, and for explanations of the large and growing proportions of unrelatedindividual and female headed households more generally has not generated particularly satisfying results. Differences in levels of education seem to explain much of the poverty gap between Hispanics (many of whom are recent immigrants) and whites, but little of the poverty gap between African Americans and whites. Many scholars believe that the legacy of racial stigma in the US that dates from slavery persists in stereotyping and discrimination. Implicit discrimination and what Glenn Loury calls discrimination in contact — in neighborhood residence, friendships, marriage and other associationsremains common, even though overt discrimination has decreased since the passage of civil rights laws in the 1960s (Loury, 2002). Racial segregation may exacerbate the differences between communities in norms of behavior, many of which can be explained by lingering racial stigma in other areas.

Ethnicity and Poverty in Mexico. In Mexico, the most important racial/ethnic difference (at least the most important that we can document) is between indigenous people, who make up about nine percent of the population, and the non-indigenous. Table 12 gives the basic data. 
Table 12. Ethnicity, Household Composition and Food Poverty, Mexico, 2000.

\begin{tabular}{|c|c|c|}
\hline & $\begin{array}{c}\text { Non- } \\
\text { Indigenous } \\
\end{array}$ & Indigenous \\
\hline \multicolumn{3}{|l|}{ Elderly } \\
\hline Percent of group & $8.0 \%$ & $7.4 \%$ \\
\hline Poverty rate & $32.3 \%$ & $56.9 \%$ \\
\hline \multicolumn{3}{|l|}{$\begin{array}{l}\text { Non-elderly unrelated individuals } \\
\text { and sub-families }\end{array}$} \\
\hline Percent of group & $1.1 \%$ & $0.7 \%$ \\
\hline Poverty rate & $18.6 \%$ & $30.2 \%$ \\
\hline \multicolumn{3}{|l|}{$\begin{array}{l}\text { Non-elderly persons in married- } \\
\text { couple families }\end{array}$} \\
\hline Percent of group & $72.9 \%$ & $79.2 \%$ \\
\hline Poverty rate & $19.5 \%$ & $52.8 \%$ \\
\hline \multicolumn{3}{|l|}{$\begin{array}{l}\text { Non-elderly persons in male- } \\
\text { headed families, no spouse }\end{array}$} \\
\hline Percent of group & $3.6 \%$ & $3.9 \%$ \\
\hline Poverty rate & $19.5 \%$ & $47.7 \%$ \\
\hline \multicolumn{3}{|l|}{$\begin{array}{l}\text { Non-elderly persons in female- } \\
\text { headed families, no spouse }\end{array}$} \\
\hline Percent of group & $14.3 \%$ & $8.9 \%$ \\
\hline Poverty rate & $23.3 \%$ & $51.7 \%$ \\
\hline Overall poverty rate & $20.7 \%$ & $52.5 \%$ \\
\hline Percent of group in population & $91.0 \%$ & $9.0 \%$ \\
\hline
\end{tabular}

Source: Author's calculations based on Mexican Population Census 2000 and poverty rates estimated by Cortés, Rodríguez y Zenteno (2004).

As with racial differences in the US, the disparities in poverty rates are striking, with the indigenous poverty rate two and a half times that for the non-indigenous. Unlike the US, however, household composition differences are not apparent. Smaller proportions of the indigenous live alone, with non-relatives or in female-headed families. The vast majority are in married couple families, with a poverty rate much greater than in married non-indigenous families. A higher poverty rate among indigenous people is more related to family size since they tend to have higher fertility (more dependents) than the rest of the population. According to the Mexican Census, households headed by indigenous persons have, on average, 4.8 members, while those headed by nonindigenous have only 4.2 members.

The incidence of poverty among indigenous people cannot be understood in isolation of the geographical and social inequality taking place in Mexico. On the one 
hand, most of the indigenous population lives in southern Mexico. Only four Mexican states (Oaxaca, Chiapas, Yucatán and Veracruz) accounted for one of every two indigenous persons in 2000. As we saw before, these states are among the poorest in Mexico. On the other hand, indigenous people in Mexico are more economically vulnerable as a result of receiving lower and poorer education than an average Mexican citizen, not to mention being exposed to higher mortality rates.

\section{Concluding Remarks}

There are obviously many other aspects of poverty and its correlates in North American that could productively be explored. But perhaps some tentative conclusions can be drawn from what we have presented here.

- We believe our exploration of poverty measures for North America illustrates the possibility of using common conceptualizations to describe poverty across very different countries.

- Overall levels of economic development and inequality, and patterns of economic growth go a long way toward explaining the large differences in poverty rates between Mexico and the other countries of North America. Accelerated economic development in Mexico is crucial to poverty alleviation in North America. It is also important, though, that economic development be pro-poor, in the sense of generating jobs and income for the lower quintiles. Mexico, which is already highly unequal in its income distribution, must pay particular attention to this issue.

- Poverty is much more strongly related to place within Mexico than within the US or Canada. The low-income southern states in Mexico have much higher poverty rates than the rest of the country, and contain a large proportion of the country's poor. At the same time, the majority of the poor, even in Mexico, do not live in the lowest-income states. Thus, although place-specific development strategies are important in Mexico, internal migration is likely to result, as it has in the US and Canada, in convergence of poverty rates. For the future, poverty alleviation strategies must also be concerned with the poor who live in urban areas, and with poverty in the midst of relative prosperity.

- Poverty is very strongly related to household composition in the US and Canada, with unrelated individual households and female headed families having much higher poverty rates that married couple families. Poverty alleviation strategies in the US and Canada must speak to both the earnings potential and the need for transfer payments of these groups.

- Poverty is not related in the same way to household composition in Mexico. It will be important, however, for Mexico to attend to the possible growth of 
economically vulnerable household types as the economy develops. Mexico would do well to prevent, if possible, the kind of growth of female-headed families that exacerbates poverty in the US and Canada.

- Poverty is very strongly related to race and ethnicity in the US and to indigenous status in Mexico. In the US, racial stigma and racial segregation continue to affect the African American population, with seriously harmful results. In Mexico, the indigenous population is isolated by geography, language, and education level, and presents a serious challenge for poverty alleviation efforts. Both countries need to be vigorous in combating discrimination and in making opportunities available for the disadvantaged. 


\section{References}

Cortés, F., H. Rodriguez and R. Zenteno. 2004. Estimaciones de pobreza a nivel estatal y municipal en México 2000. Unpublished manuscript.

Datt, G. and M. Ravallion. 1992. "Growth and redistribution components of changes in poverty measures: a decomposition with applications to Brazil and India in the 1980's”. Journal of Development Economics, 38(2): 275-295.

Deaton, Angus. 2003. “Measuring poverty”. Princeton Universuty. Unpublished manuscript.

Bourguignon, Francoise. 2004. “The poverty-growth-inequality triangle”. Paper presented at the Indian Council for Research on International Economic Relations. New Delhi.

Foster, James. 1998. “Absolute versus relative poverty”. The American Economic Review, 88(2): 335-341.

Hérnandez Laos, Enrique. 2003. "Distribución del ingreso y pobreza”, in La situación del trabajo en México, de la Garza, Enrique and Carlos Salas (coord.). México City: IET-UAM-Plaza Valdez. Pp. 97-127

Loury, Glenn C. 2002. The Anatomy of Racial Inequality. Cambridge MA: Harvard University Press.

Moynihan, Daniel P. Timothy M. Smeeding and Lee Rainwater, editors. 2004. The Future of the Family. New York: Russell Sage Foundation.

Pritchett, Lant. 1997. “Divergence, Big Time”. Journal of Economic Perspectives 11(3): 3-17.

Son, Hyun and Nanak Kakwani. 2004. "Economic growth and poverty reduction: inicial conditions matter”. Working Paper 2 of the International Poverty Centre of United Nations Development Programme.

Szekely, Miguel, Nora Lustig, Martin Cumpa and Jose Antonio Mejia.2000. “Do We Know How Much Poverty There Is?” Inter-American Development Bane, Working Paper \#437.

Weinberg, Daniel H. 2004 "Income Data Quality Issues in the Annual Social and Economic Supplement to the Current Population Survey,” Paper prepared for American Enterprise Institute-University of Maryland Seminar on Poverty Measurement. 